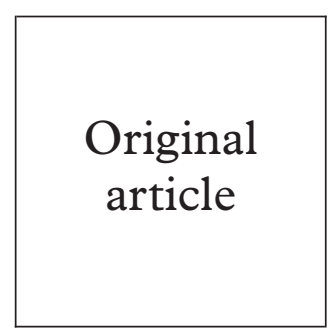

\title{
Molecular epidemiology of tetM genes in Neisseria gonorrhoeae
}

\author{
A Turner, K R Gough, J P Leeming
}

Objective: To examine the epidemiology of the tet $\mathrm{M}$ gene in Neisseria gonorrhoeae strains with high level resistance to tetracycline (TRNG) using a polymerase chain reaction (PCR) assay.

Methods: A single tube PCR was developed which distinguishes between the American and Dutch variants of the tetM gene. Between 1988 and 1995, 518 strains of TRNG (tetracycline MIC $>8 \mathrm{mg} / \mathrm{l}$ ) were referred to the Gonococcus Reference Unit by other laboratories or isolated from routine swabs taken at local clinics. The strains were analysed for plasmid content, auxotype, serovar, and the tet $\mathrm{M}$ gene type. Travel details of the patients were determined by a questionnaire.

Results: A PCR product was obtained from all TRNG examined. 387 TRNG strains produced a 778 bp PCR product (American type tet $\mathrm{M}$ ) and 131 produced a $443 \mathrm{bp}$ PCR product (Dutch type $t e t \mathrm{M}$ ). Infections acquired in the United Kingdom contributed $57 \%$ of the TRNG strains included in this study; $82 \%$ of these carried the American type of tet $\mathrm{M}$. The number of UK acquired TRNG received by the GRU increased each year except 1993-from four strains received in 1990 to 92 in 1995. After the United Kingdom, Caribbean and African countries contributed most strains, with 56 and 60 TRNG acquired in each area respectively. All strains originating in Africa, except one from South Africa, contained the American type tet $\mathrm{M}$. Infections caught in Nigeria and Kenya contributed most strains (15 and 14 respectively). The TRNG originating from Caribbean countries comprised 36\% Dutch tetM type. Infections caught in Jamaica accounted for $82 \%$ of the Caribbean strains. All 35 TRNG strains originating in the Far East contained the Dutch type tetM. 25 of the Far East strains were also penicillinase producing (PPNG). Infections originating in Indonesia accounted for $49 \%$ of the Far East strains but these belonged to 12 different auxotype/serovar combinations. A geographical variation in the type of penicillinase coding plasmids found in PPNG/TRNG was also detected.

Conclusions: These data suggest that the Dutch type tetM may have originated in the Far East and the American type in the African continent. Subsequent spread has resulted in a heterogeneous distribution of TRNG types in other parts of the world. At completion of the survey the numbers of TRNG imported each year from the major overseas sources had reached a plateau while UK contracted TRNG continued to rise providing evidence for the establishment of endemic TRNG strains in the United Kingdom.

(Sex Transm Inf 1999;75:60-66)

Keywords: epidemiology; Neisseria gonorrhoeae; tet $\mathrm{M}$; polymerase chain reaction

\section{Introduction}

Infections caused by gonococci with high level plasmid mediated resistance to tetracycline (TRNG) were first recognised in the United Kingdom in 1987. ${ }^{1}$ Isolations of TRNG have also been reported from the Netherlands, France, Spain, Canada, Africa, and Uruguay, ${ }^{2-7}$ following the original recognition of TRNG in the United States in $1985 .{ }^{8}$ Subsequent epidemiological studies have suggested a worldwide distribution for TRNG strains. ${ }^{910}$

High level tetracycline resistance (minimum inhibitory concentration (MIC) $>8 \mathrm{mg} / \mathrm{l}$ ) in gonococci is mediated by a tet $\mathrm{M}$ determinant carried on a $25.2 \mathrm{MDa}$ conjugative plasmid. ${ }^{11}$ The restriction endonuclease map of the 25.2 MDa conjugative plasmid from a TRNG strain imported from the United States has been found to differ from a map derived from a strain isolated in the Netherlands. ${ }^{12}$ These two types of tet $\mathrm{M}$ carrying conjugative plasmids were designated "American" and "Dutch" respectively. The latter had a restriction map similar to the $24.5 \mathrm{MDa}$ conjugative plasmid found in tetracycline sensitive strains of $\mathrm{N}$ gonorrhoeae whereas the map of the American type suggested a different origin. More recently the nucleotide sequences of the tet $\mathrm{M}$ genes from the American and Dutch conjugative plasmids have been determined and found to differ significantly. ${ }^{13}$

As tetracycline is a cheap drug it may still be used in some parts of the world to treat both gonorrhoea and chlamydia infection. ${ }^{14}{ }^{15}$ Laboratory tests to screen for resistance in gonococci have been described ${ }^{11}{ }^{14}{ }^{16}$; however, a rapid test that simultaneously detects and types the gene responsible for tetracycline resistance may have a role in epidemiological studies of resistance. We have designed three oligonucleotide primers that will hybridise with the tet $\mathrm{M}$ gene in a polymerase chain reaction (PCR). The results presented here describe the use of these primers to detect and type the tet $\mathrm{M}$ gene in gonococci and, together with patient demographic data, describe the global distribution of the tetM gene.

\section{Materials and methods}

SOURCES OF N GONORRHOEAE STRAINS

The gonococci used in the study were collected between 1988 and 1995. The isolates were received for confirmation and further tests from laboratories around the United Kingdom or were isolated by the Gonococcus Reference 
Unit (GRU) from routine diagnostic specimens taken at two local genitourinary medicine clinics. The identity of strains was confirmed by Gram film, oxidase reaction, and the production of acid from glucose but not maltose or sucrose in cysteine trypticase agar. The Phadebact Monoclonal GC Test (Boule Diagnostics AB, Huddinge, Sweden) was also used to confirm the identity of strains and to provide a serogroup result for strains that were not serotyped.

The World Health Organisation (WHO) set of strains designated $\mathrm{A}$ to $\mathrm{E}$ and a TRNG strain kindly provided by Dr C A Ison, St Mary's Hospital Medical School, Paddington, London, were used as controls for the antimicrobial sensitivity tests.

The PCR reaction was validated using 20 strains of $N$ gonorrhoeae, obtained from the culture collection of the GRU, carrying tet $\mathrm{M}$ conjugative plasmids with previously determined endonuclease restriction pattern type ${ }^{12}$ and tet $\mathrm{M}$ type. ${ }^{17}$ Twenty two gonococci with tetracycline MICs that were borderline for high level resistance (MIC $8 \mathrm{mg} / \mathrm{l}$ ) but did not contain the $25.2 \mathrm{MDa}$ plasmid and 16 strains of gonococci known to be carrying $24.5 \mathrm{MDa}$ conjugative plasmids in combination with penicillinase plasmids (tetracycline MIC range 1-4 mg/l) were also included. These two sets of strains were also obtained from the culture collection of the GRU. The borderline tetracycline resistant strains were originally isolated by laboratories in 12 cities in the United Kingdom and the conjugative plasmid carrying strains were isolated by laboratories in 10 cities.

ANTIBIOTIC SUSCEPTIBILITY TESTING

The agar dilution method was used. Appropriate dilutions of tetracycline were incorporated into Blood Agar Base No 2 (Difco) supplemented with $5 \%$ horse blood. A multipoint inoculator was used to deliver approximately $10^{4}$ colony forming units (cfu) of each strain onto the plates. Endpoints were read as complete inhibition of growth after 18 hours at $37^{\circ} \mathrm{C}$ in $5 \%$ carbon dioxide. WHO strains A-E and the control TRNG were included in each batch of organisms tested to ensure day to day reproducibility.

Penicillinase production was detected using a modification of the method of Hodge et $a l^{18}$ essentially utilising protection of the "Oxford" strain of Staphylococcus aureus inoculated with the test strain onto heated blood agar containing $1 \mathrm{mg} / \mathrm{l}$ ampicillin.

\section{PLASMID DETECTION}

Gonococci with a MIC of tetracycline of $\geqslant 16$ $\mathrm{mg} / \mathrm{l}$, and appropriate control strains were subcultured onto New York City agar. Growth was harvested from the plate after overnight incubation. Plasmid DNA was purified using a modification of the Birnboim and Doly method, ${ }^{19}$ separated by electrophoresis through $1 \%$ agarose gel and visualised by ultraviolet fluorescence after ethidium bromide staining.
POLYMERASE CHAIN REACTION

DNA was prepared by boiling a faintly turbid suspension (equivalent to McFarland No 1 standard) of gonococcal cells (grown on New York City agar) with 5\% Chelex 100 resin (Bio-Rad) for 15 minutes; resin and cellular debris were removed by brief centrifugation. The PCRs were performed in a total volume of $50 \mu \mathrm{l}$ containing $0.25 \mathrm{U}$ of Taq polymerase (Super Taq, HT Biotechnology Ltd), buffer (10 mM TRIS-HCl pH 9.0, $1.5 \mathrm{mM} \mathrm{MgCl}_{2}$, $50 \mathrm{mM} \mathrm{KCl}, 0.1 \% \mathrm{v} / \mathrm{v}$ Triton X-100, $0.01 \%$ w/v gelatin), $20 \mu \mathrm{M}$ of each dNTP (Pharmacia), and $0.1 \mu \mathrm{M}$ of each of the three primers. A universal forward primer (UF) that hybridises with both variants was combined with reverse primers specific to each variant (AR (American) and DR (Dutch)). The primer sequences, derived from the sequences of pOZ100 (UF, AR) and pOZ101 (DR), ${ }^{13}$ were:

Primer UF:

$5^{1}{ }^{825}$ CTCGAACAAGAGGAAAGC ${ }^{842}$

Primer AR:

$5^{1}{ }^{1602}$ GCATTCCACTTCCCAAC ${ }^{1586}$

Primer DR:

5' ${ }^{1267}$ TGCAGCAGAGGGAGG ${ }^{1253}$

The GenBank accession number for the tet $\mathrm{M}$ gene sequence for $\mathrm{pOZ} 100$ is L12241 and that for pOZ101 is L12242. The prepared DNA (2 $\mu \mathrm{l})$ was added, the reaction mixture overlaid with two drops of paraffin oil and transferred to the thermal cycler (Omnigene, Hybaid, UK). The reaction mixture was incubated at $94^{\circ} \mathrm{C}$ for 3 minutes and then 30 cycles of PCR were performed consisting of denaturing for $20 \mathrm{sec}-$ onds at $94^{\circ} \mathrm{C}$, annealing for 1 minute at $55^{\circ} \mathrm{C}$ and extension for 1 minute 30 seconds at $72^{\circ} \mathrm{C}$. In the final cycle there was a step of 7 minutes at $72^{\circ} \mathrm{C}$ to complete extension. The expected product sizes of this PCR assay were 778 and 443 base pairs from the American and Dutch types of tet $\mathrm{M}$ respectively.

A control "Dutch" tet $\mathrm{M}$ carrying strain (GR7698), a control "American" tetM strain (GR7646), and a negative control strain (SB5) carrying the $24.5 \mathrm{MDa}$ conjugative plasmid were included in each PCR experiment.

PCR products were analysed by electrophoresis in $1 \% \mathrm{w} / \mathrm{v}$ agarose and visualised by ultraviolet fluorescence after ethidium bromide staining.

To confirm the identity of the PCR amplicons, the PCR products from 12 gonococcal isolates (three controls and three test strains of each tet $\mathrm{M}$ type) were digested with Taq-1 endonuclease and the restriction products visualised after electrophoresis on $10 \%$ polyacrylamide gel. The restriction product sizes predicted were distinct for amplicons from the American and Dutch type tet $M$ types even if a $443 \mathrm{bp}$ (Dutch type) product were generated from an American type tet $\mathrm{M}$ by mispriming.

\section{AUXOTYPING}

The defined medium of Copley and Egglestone $^{20}$ was used to test for nutritional requirement for proline, arginine, hypoxanthine, and uracil. In addition, the ability of ornithine to replace a requirement for arginine was tested. 


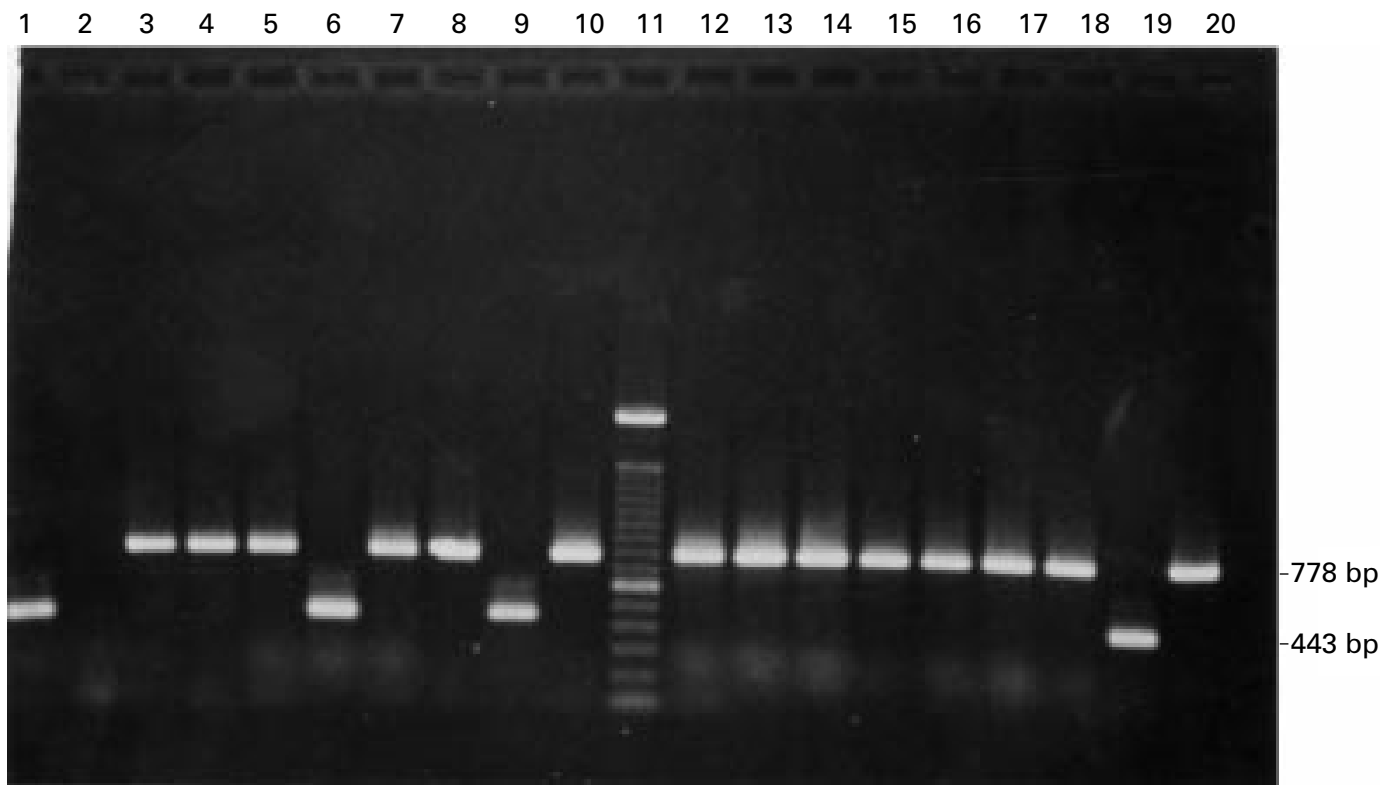

Figure 1 Ethidium bromide stained agarose gel electrophoresis of polymerase chain reaction products using tet $M$ type specific reverse primers $A R$ and DR combined with a universal forward primer (UF) with DNA from tetracycline resistant $N$ gonorrhoeae. Lane 11: 100 base pair ladder molecular weight standard. Lane 1: Dutch type tetM control strain (GR7698), lane 2: negative (tetracycline sensitive) control strain (SB5), lane 3: American type tetM control strain (GR7646). Lanes 4, 5, 7, 8, 10, 12-18, and 20: American type tetM strains (778 base pair PCR product). Lanes 6, 9, and 19: Dutch type tetM strains (443 base pair PCR product).

\section{SEROTYPING}

Monoclonal antibodies raised against the major outer membrane protein I of $N$ gonorrhoeae produced by Genetic Systems (GS) (supplied by Syva, Palo Alto, CA, USA) were used to serotype strains. Six monoclonal antibodies were specific for protein IA strains and six were specific for protein IB strains. Test strains were suspended in PBS and boiled for 10 minutes, after cooling a drop of this was added to an equal volume of each monoclonal antibody coated Staphylococcus aureus suspension on a glass slide. The co-agglutination reaction pattern with each panel was read after gentle rocking for 2 minutes and the nomenclature scheme of Knapp et $a l^{21}$ was used to determine the serovar.

Table 1 Phenotype and origin of 20 strains of Neisseria gonorrhoeae used to validate the tetM gene typing

\begin{tabular}{|c|c|c|c|c|c|c|c|}
\hline $\begin{array}{l}\text { Laboratory } \\
\text { number }\end{array}$ & $\begin{array}{l}\text { Tet } M \\
\text { yene type } \\
\text { by PCR } R^{\star}\end{array}$ & $\begin{array}{l}\text { Published } \\
\text { TetM gene } \\
\text { typet }\end{array}$ & $\begin{array}{l}\text { Plasmid } \\
R f \\
\text { type } \neq\end{array}$ & $\begin{array}{l}\text { Tetracycline } \\
\text { MIC } \\
(m g / l)\end{array}$ & $\begin{array}{l}\text { Plasmid } \\
\text { profile (MDa) }\end{array}$ & $\begin{array}{l}\text { AuxotypeS/ } \\
\text { serovar }\end{array}$ & $\begin{array}{l}\text { Country of } \\
\text { acquisition }\end{array}$ \\
\hline GR7418 & A & A & A & 32 & $2.6,25.2$ & Arg $/ \mathrm{IB} 2$ & UK \\
\hline GR7575 & A & A & A & 32 & $2.6,25.2$ & NR/IB2 & Unknown \\
\hline GR7646 & A & A & A & 32 & $2.6,25.2$ & NR/IB2 & Unknown \\
\hline GR7647 & A & A & A & 32 & $2.6,25.2$ & NR/IB2 & Unknown \\
\hline GR7785 & A & A & A & 64 & $2.6,3.2,25.2$ & NR/IB5 & Zaire \\
\hline GR7891 & A & A & A & 32 & $2.6,25.2$ & NR/IB16 & UK \\
\hline GR8122 & A & A & A & 32 & $2.6,3.2,25.2$ & NR/IB1 & Jamaica \\
\hline GR8224 & A & A & A & 32 & $2.6,3.2,25.2$ & Pro $/$ IA 6 & Kenya \\
\hline GR8258 & A & A & A & 32 & $2.6,3.2,25.2$ & Pro $-/$ IA6 & Kenya \\
\hline GR8260 & A & A & A & 32 & $2.6,3.2,25.2$ & $\mathrm{Pro}^{-} / \mathrm{IA} 6$ & UK \\
\hline GR8958 & A & A & A & 32 & $2.6,3.2,25.2$ & $\mathrm{Arg} / \mathrm{IB} 2$ & W. Indies \\
\hline GR8813 & A & A & D & 32 & $2.6,4.4,25.2$ & NR/IA6 & Gabon \\
\hline GR7272 & $\mathrm{D}$ & $\mathrm{D}$ & $\mathrm{D}$ & 32 & $2.6,3.2,25.2$ & NR/IB6 & Unknown \\
\hline GR7307 & $\mathrm{D}$ & $\mathrm{D}$ & $\mathrm{D}$ & 32 & $2.6,3.2,25.2$ & NR/IB6 & UK \\
\hline GR7698 & $\mathrm{D}$ & $\mathrm{D}$ & $\mathrm{D}$ & 16 & $2.6,3.2,25.2$ & Arg-/IA2 & Brazil \\
\hline GR7926 & $\mathrm{D}$ & $\mathrm{D}$ & $\mathrm{D}$ & 32 & $2.6,3.2,25.2$ & $\mathrm{Pro}^{-} / 1 \mathrm{~B} 4$ & Colombia \\
\hline GR8104 & $\mathrm{D}$ & $\mathrm{D}$ & $\mathrm{D}$ & 16 & $2.6,3.2,25.2$ & NR/IB3 & Jamaica \\
\hline GR8136 & $\mathrm{D}$ & $\mathrm{D}$ & $\mathrm{D}$ & 16 & $2.6,3.2,25.2$ & NR/IB3 & Jamaica \\
\hline GR8219 & $\mathrm{D}$ & $\mathrm{D}$ & D & 32 & $2.6,25.2$ & NR/IB3 & Netherlands \\
\hline GR8617 & $\mathrm{D}$ & D & D & 16 & $2.6,3.2,25.2$ & NR/IB6 & UK \\
\hline
\end{tabular}

*tet $\mathrm{M}$ type results obtained from the PCR assay described in the current study. A = American-type tet $\mathrm{M}$ gene or plasmid, and $\mathrm{D}=$ Dutch type

tData from Gascoyne-Binzi et al ${ }^{17}$ and Professor PM Hawkey (personal communication).

$\neq$ Conjugative plasmid restriction endonuclease pattern data from Gascoyne et al. ${ }^{12}$

\Auxotypes are as follows: arginine requiring $\left(\mathrm{Arg}^{-}\right)$; non-requiring (NR); proline requiring $\left(\mathrm{Pro}^{-}\right)$.
DEMOGRAPHIC DATA

A questionnaire was issued to the referring laboratory or clinic with the laboratory report of each tetracycline resistant gonococcus. This allowed information to be gathered on the travel history of the patient and other demographic information.

\section{Results}

The PCR assay gave a product consistent with the predicted size of $778 \mathrm{bp}$ from the American type and $443 \mathrm{bp}$ from the Dutch type of tetM (fig 1). The $778 \mathrm{bp}$ product was obtained from all 12 strains of $N$ gonorrhoeae known to be carrying American tet $\mathrm{M}$ type, and a $443 \mathrm{bp}$ product was obtained from all eight strains of $N$ gonorrhoeae carrying Dutch tetM type (table 1).

Restriction fragment analysis using Taq-1 was performed on the PCR amplicons from 12 gonococcal isolates (three controls and three test strains of each tet $\mathrm{M}$ type). Products of the predicted sizes $(74,130$, and $572 \mathrm{bp}$ for the $778 \mathrm{bp}$ amplicons and 126,130 , and $185 \mathrm{bp}$ for the $443 \mathrm{bp}$ amplicons: predicted $2 \mathrm{bp}$ products from both types were not visualised) were found in preparations made from all strains.

The specificity of the PCR assay was tested using DNA preparations from 16 tetracycline sensitive penicillinase producing strains carrying the $24.5 \mathrm{MDa}$ conjugative plasmid (table 2) and 22 strains with tetracycline MICs of $8 \mathrm{mg} / 1$. No product of any size was detected in the PCR assay from these two groups of strains.

In all, 518 strains of TRNG isolated in the United Kingdom but originating from infections acquired in 39 countries worldwide as well as the United Kingdom, were tested in the tetM PCR assay. A total of 387 TRNG strains produced $778 \mathrm{bp}$ PCR products (American 
Table 2 Results obtained from the PCR assay with 16 gonococci containing 24.5 MDa conjugative plasmids and 518 tetracycline resistant gonococci

\begin{tabular}{lllll}
\hline & \multicolumn{5}{l}{ PCR product } \\
\cline { 3 - 5 } Plasmid content $(M D a)$ & No & American & Dutch & None \\
\hline $2.6+3.0+24.5$ & 5 & 0 & 0 & 5 \\
$2.6+3.2+24.5$ & 10 & 0 & 0 & 10 \\
$2.6+4.4+24.5$ & 1 & 0 & 0 & 1 \\
$2.6+25.2$ & 153 & 111 & 42 & 0 \\
$2.6+3.0+25.2$ & 1 & 0 & 1 & 0 \\
$2.6+3.2+25.2$ & 318 & 257 & 61 & 0 \\
$2.6+4.4+25.2$ & 46 & 19 & 27 & 0 \\
\hline
\end{tabular}

type tet $\mathrm{M})$ and 131 produced $443 \mathrm{bp}$ PCR products (Dutch tetM) (table 2).

$\beta$ Lactamase production was detected in $71 \%$ of TRNG strains carrying the American tet $\mathrm{M}$ and $68 \%$ of strains containing the Dutch tet $\mathrm{M}$. The American type of tet $\mathrm{M}$ was found in $81 \%$ of TRNG strains carrying the $3.2 \mathrm{MDa}$ $\beta$ lactamase plasmid but was found in only $41 \%$ of strains carrying the $4.4 \mathrm{MDa}$ plasmid.

The first TRNG strains were received by the GRU during 1988, one infection was acquired in Jamaica while three others had an unknown origin (table 3). One TRNG was received in 1989 and 30 in 1990 of which four were acquired in the United Kingdom. Overall, infections acquired in the United Kingdom contributed $57 \%$ (296 of 518 ) of the TRNG strains included in this study. Two hundred and forty two $(82 \%)$ of these carried the American type of tet $\mathrm{M}$.

After the United Kingdom, Caribbean and African countries contributed most strains with
56 and 60 TRNG acquired in each area respectively. All strains originating in Africa, except one from South Africa yielded PCR products characteristic of the American type tet $\mathrm{M}$. Infections caught in Nigeria and Kenya contributed most strains, 15 and 14 respectively (table 3) -28 of these were also PPNG and $21(75 \%)$ contained the $3.2 \mathrm{MDa} \beta$ lactamase plasmid. Four auxotype/serovar (A/S) types were found among Kenyan strains, eight $(57 \%)$ were proline requiring/IA6 and contained the 3.2 MDa $\beta$ lactamase plasmid. Six A/S types were found among Nigerian strains, five isolates $(33 \%)$ were proline requiring/IA6, three of these contained the $3.2 \mathrm{MDa} \beta$ lactamase plasmid.

The TRNG originating from Caribbean countries comprised 36\% (20/56) Dutch tetM type. Infections caught in Jamaica accounted for $46(82 \%)$ of the strains in contrast with one from Barbados and two from Cuba (all three American type tet M) (table 3). American type tet $\mathrm{M}$ was detected in $29(63 \%)$ of Jamaican TRNG, 20 of these $29(69 \%)$ were PPNG. Penicillinase production was detected in 12 (71\%) of the 17 Jamaican TRNG carrying the Dutch tetM type. All PPNG/TRNG acquired in Jamaica carried the $3.2 \mathrm{MDa} \beta$ lactamase plasmid. Jamaican TRNG carrying the American tet $\mathrm{M}$ type belonged to 10 different $\mathrm{A} / \mathrm{S}$ types although $11(38 \%)$ were non-requiring/ IB2 and 10 of the 11 were PPNG. Jamaican TRNG carrying the Dutch tet $\mathrm{M}$ type belonged to nine different $\mathrm{A} / \mathrm{S}$ types, the most frequent

Table 3 Reported geographical origin and tetM genotype of tetracycline resistant Neisseria gonorrhoeae strains received by the Gonococcus Reference Unit 1988-95

\begin{tabular}{|c|c|c|c|c|c|c|c|c|c|c|}
\hline \multirow{2}{*}{$\begin{array}{l}\text { Geographical area/major } \\
\text { country of acquisition }\end{array}$} & \multirow[b]{2}{*}{ tetM Type } & \multicolumn{8}{|l|}{ Year } & \multirow[b]{2}{*}{ Total } \\
\hline & & 1988 & 1989 & 1990 & 1991 & 1992 & 1993 & 1994 & 1995 & \\
\hline \multicolumn{11}{|l|}{ Africa } \\
\hline Total & $\begin{array}{l}\text { American } \\
\text { Dutch }\end{array}$ & & & 4 & 9 & 7 & 9 & $\begin{array}{l}16 \\
1\end{array}$ & 14 & $\begin{array}{l}59 \\
1\end{array}$ \\
\hline Kenya & $\begin{array}{l}\text { American } \\
\text { Dutch }\end{array}$ & & & 2 & 4 & 2 & 4 & 1 & 1 & $\begin{array}{l}14 \\
0\end{array}$ \\
\hline Nigeria & $\begin{array}{l}\text { American } \\
\text { Dutch }\end{array}$ & & & & 2 & 4 & & 6 & 3 & $\begin{array}{l}15 \\
0\end{array}$ \\
\hline South Africa & $\begin{array}{l}\text { American } \\
\text { Dutch }\end{array}$ & & & & & & & 1 & 1 & $\begin{array}{l}1 \\
1\end{array}$ \\
\hline \multicolumn{11}{|c|}{ North, central, and South America } \\
\hline Total & $\begin{array}{l}\text { American } \\
\text { Dutch }\end{array}$ & & & 2 & 1 & $\begin{array}{l}3 \\
0\end{array}$ & & $\begin{array}{l}1 \\
2\end{array}$ & 1 & $\begin{array}{l}4 \\
6\end{array}$ \\
\hline \multicolumn{11}{|l|}{ Caribbean } \\
\hline Total & $\begin{array}{l}\text { American } \\
\text { Dutch }\end{array}$ & 1 & & $\begin{array}{l}4 \\
4\end{array}$ & $\begin{array}{l}12 \\
3\end{array}$ & $\begin{array}{l}9 \\
8\end{array}$ & $\begin{array}{l}2 \\
1\end{array}$ & $\begin{array}{l}2 \\
1\end{array}$ & $\begin{array}{l}7 \\
2\end{array}$ & $\begin{array}{l}36 \\
20\end{array}$ \\
\hline Barbados & $\begin{array}{l}\text { American } \\
\text { Dutch }\end{array}$ & & & & & 1 & & & & $\begin{array}{l}1 \\
0\end{array}$ \\
\hline Cuba & $\begin{array}{l}\text { American } \\
\text { Dutch }\end{array}$ & & & & & & & & 2 & $\begin{array}{l}2 \\
0\end{array}$ \\
\hline Jamaica & $\begin{array}{l}\text { American } \\
\text { Dutch }\end{array}$ & 1 & & $\begin{array}{l}3 \\
3\end{array}$ & $\begin{array}{l}9 \\
2\end{array}$ & $\begin{array}{l}8 \\
7\end{array}$ & 2 & 2 & $\begin{array}{l}5 \\
2\end{array}$ & 29 \\
\hline \multicolumn{11}{|l|}{ Europe } \\
\hline Total & $\begin{array}{l}\text { American } \\
\text { Dutch }\end{array}$ & & & $\begin{array}{l}2 \\
4\end{array}$ & $\begin{array}{l}37 \\
7\end{array}$ & $\begin{array}{l}42 \\
16\end{array}$ & $\begin{array}{l}20 \\
7\end{array}$ & $\begin{array}{l}58 \\
18\end{array}$ & $\begin{array}{l}89 \\
6\end{array}$ & $\begin{array}{l}248 \\
58\end{array}$ \\
\hline UK & $\begin{array}{l}\text { American } \\
\text { Dutch }\end{array}$ & & & $\begin{array}{l}2 \\
2\end{array}$ & $\begin{array}{l}36 \\
7\end{array}$ & $\begin{array}{l}41 \\
15\end{array}$ & $\begin{array}{l}20 \\
7\end{array}$ & $\begin{array}{l}56 \\
18\end{array}$ & $\begin{array}{l}87 \\
5\end{array}$ & $\begin{array}{l}242 \\
54\end{array}$ \\
\hline \multicolumn{11}{|l|}{ Far East } \\
\hline Total & $\begin{array}{l}\text { American } \\
\text { Dutch }\end{array}$ & & & 1 & 8 & 4 & 9 & 5 & 8 & $\begin{array}{l}0 \\
35\end{array}$ \\
\hline Indonesia & American & & & & & & & & & 0 \\
\hline & Dutch & & & 1 & 7 & 2 & 3 & 3 & 1 & 17 \\
\hline Philippines & American & & & & & & & & & 0 \\
\hline & Dutch & & & & & & & & 2 & 2 \\
\hline Thailand & American & & & & & & & & & 0 \\
\hline & Dutch & & & & & 1 & 2 & 1 & 4 & 8 \\
\hline Unknown & American & 3 & 1 & 7 & 17 & 2 & & 1 & 9 & 40 \\
\hline & Dutch & & & 2 & 8 & & & 1 & & 11 \\
\hline Total & American & 3 & 1 & 17 & 75 & 63 & 31 & 78 & 119 & 387 \\
\hline & Dutch & 1 & 0 & 13 & 27 & 28 & 17 & 28 & 17 & 131 \\
\hline
\end{tabular}


was non-requiring/IB3 (five of 17, 29\%) and three of these were PPNG.

All 35 TRNG strains originating in the Far East contained the Dutch type tet $\mathrm{M}$ (table 3). Penicillinase production was detected in 25 (71\%) of the 35 Far East strains, 24 of these carried the 4.4 MDa $\beta$ lactamase plasmid and the other was a $3.0 \mathrm{MDa} \beta$ lactamase plasmid in a strain originating in the Philippines. Overall, a total of 27 TRNG/PPNG strains carrying the 4.4 MDa $\beta$ lactamase plasmid and Dutch type tet $\mathrm{M}$ were detected from all sources (table $2)$. The three non-Far East strains with this plasmid pattern originated in Greece, Honduras, and the United Kingdom. Infections originating in Indonesia accounted for 17 (49\%) of the 35 Far East strains with only Thailand (eight) providing more than three strains over the 8 year period (table 3 ). Of the 17 strains originating from Indonesia $14(82 \%)$ were PPNG, these belonged to 12 different $\mathrm{A} / \mathrm{S}$ combinations; however, eight were the nonrequiring auxotype and of these four were the IA6 and three the IA4 serovar.

\section{Discussion}

In this study we have reported the development of a PCR technique which enables the simultaneous detection and typing of the tet $\mathrm{M}$ gene in gonococci. Complete agreement of tet $\mathrm{M}$ type was achieved with 20 strains of TRNG that had been examined using a restriction fragment polymorphism method reported by GascoyneBinzi et al. ${ }^{17}$ The PCR method reported here was applied to all 518 tetracycline resistant gonococci referred to the Gonococcus Reference Unit between 1988 and 1995. A PCR product was obtained from all strains and the product size always corresponded to that obtained from either the Dutch (443 bp) or the American (778 bp) type of tet $\mathrm{M}$ gene.

Two other PCR based methods for the detection and typing of the tetracycline resistance genotype in gonococci have been described. Ison et al described a PCR-RFLP assay in which the tet $\mathrm{M}$ gene is amplified by PCR but requires endonuclease digestion to discriminate between the American and Dutch types. ${ }^{14}$ Xia et al describe a differential PCR assay which does not require post-amplification restriction analysis. ${ }^{22}$ However the deletion responsible for the different sizes of products in this assay is downstream of the tet $\mathrm{M}$ gene and therefore the heterogeneity detected may not be reflected in the tet $\mathrm{M}$ nucleotide sequence. To facilitate this survey of the geographical distribution of tet $\mathrm{M}$ determinants we developed a simple single tube PCR assay which was specific to the tet $\mathrm{M}$ gene and did not require restriction of products. This assay could also be used to detect and characterise the tet $\mathrm{M}$ gene if it became integrated into the chromosome, as has been reported in non-pathogenic Neisseria ${ }^{22}$ but not, as yet, gonococci.

The tet $\mathrm{M}$ gene detection and typing data, together with collected travel and contact information, was used to describe the global distribution of TRNG as sampled by travellers diagnosed and treated for gonorrhoea in the United Kingdom. Although TRNG first ap- peared in the United Kingdom in $1987^{1}$ our data suggest that they did not become established until 1990. After this date there has been a steady rise in the numbers of TRNG infections contracted in the United Kingdom; four strains were received by the GRU in 1990 and by 1995 the number had risen to 92 . Over the period of study $82 \%$ of UK acquired TRNG contained the American type tetM gene. Overall, $75 \%$ of TRNG received by the GRU contained the American type tet $\mathrm{M}$ gene. The rise in incidence in the United Kingdom provides evidence for persistence of TRNG in the United Kingdom as the numbers of TRNG imported each year from the major overseas areas (Africa, the Caribbean, and the Far East) have remained approximately constant from 1991 to 1995 . The establishment of TRNG strains in the United Kingdom was predicted as early as 1990 as a likely result of the use of tetracyclines to treat chlamydia infections and pelvic inflammatory disease. ${ }^{23}$

All TRNG strains isolated from patients infected in South East Asia were found to carry the Dutch tet $\mathrm{M}$ gene. All penicillinase producing TRNG originating in this region carried the 4.4 MDa plasmid except one previously reported $^{24}$ isolate from the Philippines which possessed a 3.0 MDa plasmid. This strain also demonstrated high level resistance to ciprofloxacin (MIC $16 \mathrm{mg} / \mathrm{l}$ ). Other studies ${ }^{25}{ }^{26}$ have detected 3.2 MDa plasmids in PPNG isolated in the Far East but none was also TRNG. The type of tet $\mathrm{M}$ gene has been reported in one other study of Asian TRNG; of three strains isolated in Japan, one American type was found in an infection originating in Japan during 1985, and two Dutch tetM strains were found, one originating in Thailand in 1991 and the other was of unknown origin. ${ }^{27}$ The WHO Western Pacific Region Gonococcal Antimicrobial Surveillance Programme (GASP) has revealed considerable differences in incidence in TRNG, isolated between 1992 and 1994, across this region, ranging from $0 \%$ in Japan to $100 \%$ in the Philippines. ${ }^{28}$ Only Vietnam showed a significant rise in incidence during the period of study. The GASP study did not include Indonesia where most of the South East Asian TRNG originated from in the present study. However, a study of gonococci isolated during 1992-3 from female Indonesian sex workers revealed $98 \%$ of strains were TRNG. ${ }^{29}$ Most of the TRNG isolated from these patients belonged to the proline requiring/IA8 $\mathrm{A} / \mathrm{S}$ class in contrast with the strains in the present study where considerable heterogeneity was found. In a smaller study in the Philippines ${ }^{26}$ most (5/6) TRNG or TRNG/ PPNG were the arginine requiring/IA4 A/S class although there was heterogeneity among other gonococci in the study.

The emergence and spread of TRNG in west and central African countries is well documented. ${ }^{6} 153031$ In contrast, no TRNG were detected during 1990-3 in a study of isolates made from symptomatic men conducted in Durban, South Africa, ${ }^{32}$ or in Carltonville, South Africa between 1989 and $1990 .^{33}$ In most studies few data exist about the genetic 
basis of the resistance other than plasmid size, although in isolates from Zaire the presence of tet $\mathrm{M}$ was confirmed by DNA hybridisation and the plasmid was demonstrated to be of the American type. ${ }^{6}$ In the present study, travellers visiting Kenya and Nigeria contributed most $(29 / 60)$ of the TRNG infections originating in Africa. All TRNG strains from east, west, and central Africa contained the American type of tetM. All TRNG strains acquired in southern Africa except one from South Africa were also of the American type. A recent study of antibiotic resistant gonococci isolated in southern Africa did not detect TRNG in 55 isolates from South Africa but did find 11 TRNG among 19 isolates from Namibia and Botswana; all 11 carried the American type of tet $\mathrm{M}$ gene. ${ }^{34}$ The high prevalence of proline requiring and IA6 serovar tetracycline resistant strains in African countries ${ }^{6}{ }^{15}{ }^{30}$ was confirmed in the present study. The TRNG originating from the two most common sources, Kenya and Nigeria, comprised $57 \%$ and $33 \%$, respectively, of this A/S class although three other A/S classes were found in Kenyan strains and five in Nigerian strains.

The island of Jamaica provided the first high level tetracycline resistant isolate of $N$ gonorrhoeae in the present study, although three other isolates of unknown origin were also received in 1988. Over the period of the study Jamaica accounted for $82 \%$ of strains originating from the Caribbean region. In contrast with Africa and the Far East the TRNG originating from the Caribbean were of a mixed tet $\mathrm{M}$ type with $65 \%$ American type. A previous study has documented a high rate $(69 \%)$ of TRNG among Jamaican gonococci isolated between October 1990 and March 1991.35 As in the current study, all PPNG among the Jamaican study isolates carried the $3.2 \mathrm{MDa} \beta$ lactamase plasmid although a previous survey of Jamaican strains isolated in 1983-4 had detected six strains out of 20 PPNG that carried the Asian (4.4 MDa) plasmid. ${ }^{36}$ The results obtained from a survey of plasmid mediated antibiotic resistance in gonococci in Jamaica ${ }^{35}$ indicated there was heterogeneity among tetracycline resistant strains. The TRNG and TRNG/ PPNG in this study were found to belong to eight and $11 \mathrm{~A} / \mathrm{S}$ classes respectively. This was confirmed by the present study where $10 \mathrm{~A} / \mathrm{S}$ classes were found in strains carrying the American tet $\mathrm{M}$ type and nine $\mathrm{A} / \mathrm{S}$ classes among the strains carrying the Dutch type.

The data presented here provide evidence for a variation in the global distribution of variants of the tet $\mathrm{M}$ gene. The distribution suggests that the Dutch type of tetM may have originated in the Far East, possibly in Indonesia, and that the American type may have originated in the equatorial regions of the African continent. International travel has since distributed both types of tet $\mathrm{M}$ to other parts of the world and heterogeneity of auxotype/serovar class would indicate that interstrain distribution of the tet $\mathrm{M}$ gene has also taken place. At completion of the survey the numbers of TRNG imported each year from the major overseas sources had reached a plateau while
UK contracted TRNG continued to rise, providing evidence for the establishment of endemic TRNG strains in the United Kingdom.

The authors thank Ms M Hemming for excellent technical assistance, Dr C A Ison for supply the of serotyping reagents, D Jephcott for critical review of the manuscript, and last but by no means least, the many departments of microbiology and genitourinary medicine that have provided us with gonococcal isolates and patient information

Contributors: The project was initiated and designed by Drs Turner and Leeming. The laboratory work was carried out by Mrs Gough under the supervision of and with the aid of Dr Mrs Gough under the supervision of and with the aid of $\mathrm{Dr}$
Turner. The manuscript was written collaboratively by $\mathrm{Dr}$ Turner. The manuscript was written

Waugh MA, Lacey CJN, Hawkey PM, et al. Spread of Neisseria seria gonorrhoeae resistant to tetracycline
United States of America. BMF 1988;298:898.

2 Roberts MC, Wagenvoort JHT, Van Klingeren B, et al. TetM and $\beta$-lactamase-containing Neisseria gonorrhoeae (tetracycline resistant and penicillinase producing) in The Netherlands. Antimicrob Agents Chemother 1988;32:158.

3 Casin I, Perene F, Issoire C, et al. High-level tetracycline resistance in penicillinase-producing Neisseria gonorrhoeae in France. Eur $\mathscr{f}$ Clin Microbiol Infect Di 1989;8:929-31.

4 Vazquez JA, Berron S, Menéndez B. Isolate of TET $M$-containing Neisseria gonorrhoeae (TRNG) in Spain. Genitourin Med 1990;66:303-4.

5 Dillon JA, Carballo M. Molecular epidemiology and novel combinations of auxotype, serovar and plasmid content in combinations of auxotype, serovar and plasmid content in Canada Can f Microbiol 1990;36:64-7.

6 van Dyck E, Rossau R, Duhamel M, et al. Antimicrobial susceptibility of Neisseria gonorrhoeae in Zaire: high leve plasmid-mediated tetracycline resistance in Central Africa. Genitourin Med 1992;68:111-6.

7 Marquez C, Xia M, Borthagaray G, et al. The first molecular characterization of tetracycline-resistant Neisseria gonorrhoeae from Uruguay. $\mathcal{F}$ Antimicrob Chemother 1996;37 839-41.

8 Centers for Disease Control. Tetracycline-resistant Neisseria gonorrhoeae-Georgia, Pennsylvania, New Hampshire. MMWR 1985;34:563-70.

9 Gascoyne-Binzi DM, Hawkey PM, Heritage J, et al. Worldwide distribution of high level tetracycline-resistant Neissewide distribution of high level tetracycline-resist

10 Turner A, Gough KR, Jephcott AE. Epidemiology of tetracycline-resistant Neisseria gonorrhoeae isolated in the UK, 1988-1991. In: Conde-Glez CJ, Morse S, Rice P, Sparling F, Calderon E, eds. Pathobiology and immunobiol ogy of Neisseriaceae. Proceedings of the Eighth International Pathogenic Neisseria Conference. Cuernavarca, Mexico. INSP, 1994:305-12.

1 Morse SA, Johnson SR, Biddle JW, et al. High-level tetracycline resistance in Neisseria gonorrhoeae is result of acquisition of streptococcal tetM determinant. Antimicrob Agents Chemother 1986;30:664-70.

12 Gascoyne DM, Heritage J, Hawkey PM, et al. Molecular evolution of tetracycline-resistance plasmids carrying tetM found in Neisseria gonorrhoeae from different countries. $\mathcal{F}$ Antimicrob Chemother 1991;28:173-83.

13 Gascoyne-Binzi DM, Heritage J, Hawkey PM. Nucleotide sequences of the tet $(M)$ genes from the American and Dutch type thracycline resistance plasmids of Neisseria Dutch type tetracycline resistance plasmids of Neisser
gonorrhoeae. F Antimicrob Chemother 1993;32:667-76.

14 Ison CA, Tekki N, Gill MJ. Detection of the tetM determiIson CA, Tekki N, Gill MJ. Detection of the tetM determi-
nant in Neisseria gonorrhoeae. Sex Transm Dis 1993;20 329-33.

15 Van Dyck E, Crabbe F, Nzila N, et al. Increasing resistance of Neisseria gonorrhoeae in West and Central Africa. Consequences on therapy of gonococcal infection. Sex Transm Dis 1997;24:32-7.

16 Communicable Disease Report. Tetracycline resistant Neisseria gonorrhoeae (TRNG). CDR 1987:47.

17 Gascoyne-Binzi DM, Hawkey PM, Heritage J. The distribution of variants of the TetM determinant in tetracycline-resistant Neisseria gonorrhoeae. $\mathcal{f}$ Antimicrob tetracycline-resistant Neisseria

18 Hodge W, Ciak J, Tramont EC. Simple method for the detection of penicillinase producing Neisseria gonordetection of penicillinase producing
rhoeae. F Clin Microbiol 1978;7:102-3.

19 Bennett PM, Heritage J, Hawkey PM. An ultra-rapid method for the study of antibiotic resistance plasmids. $f$ Antimicrob Chemother 1986;18:421-4.

20 Copley CG, Egglestone SI. Auxotyping of Neisseria gonorrhoeae isolated in the United Kingdom. $\mathcal{F}$ Med Microbio 1983;16:295-302

21 Knapp JS, Tam MR, Nowinski RC, et al. Serological classification of Neisseria gonorrhoeae with use of monoclonal antibodies to gonococcal outer membrane protein I. 7 Infect Dis 1984;150:44-8.

22 Xia M, Pang Y, Roberts MC. Detection of two groups of 25.2MDa Tet M plasmids by polymerase chain reaction of the downstream region. Mol Cellular Probes 1995;9:327-2.

23 Easmon CSF. The changing pattern of antibiotic resistance of Neisseria gonorrhoeae. Genitourin Med 1990;66:55-6.

24 Turner A, Gough KR, Jephcott AE, et al. Importation into the UK of a strain of Neisseria gonorrhoeae resistant to 
penicillin, ciprofloxacin and tetracycline Genitourin Med 1995; $71: 265-9$.

25 Sarafian SK, Chu M-L, Jojima H, et al. Distribution of the 3.05 Mdal "Toronto" $\beta$-lactamase plasmid among penicillinase-producing isolates of Neisseria gonorrhoeae in the Far East. Sex Transm Dis 1991;18:201-4.

26 Knapp JS, Mesola VP, Neal SW, et al. Molecular epidemiology, in 1994, of Neisseria gonorrhoeae in Manila and Cebu City, Republic of the Philippines. Sex Transm Dis 1997;24: 2-7.

27 Kuroki T, Murase T, Watanabe Y, et al. Characterisation of high level tetracycline resistant Neisseria gonorrhoeae isolates. Genitourin Med 1997;73:421-2.

28 WHO Western Pacific Region Gonococcal Antimicrobial Surveillance Programme. Surveillance of antibiotic susceptibility of Neisseria gonorrhoeae in the WHO Western tibility of Neisseria gonorrhoeae in the WHO Western

29 Poesoef MR, Knapp JS, Idajadi A, et al. Antimicrobial Joesoef MR, Knapp JS, Idajadi A, et al. Antimicrobial
susceptibilities of Neisseria gonorrhoeae strains isolated in Surabaya, Indonesia. Antimicrob Agents Chemother 1994;38: 2530-3

30 West B, Changalucha J, Grosskurth $\mathrm{H}$, et al. Antimicrobial susceptibility, auxotype and plasmid content of Neisseri gonorrhoeae in northern Tanzania: emergence of high leve plasmid mediated tetracycline resistance. Genitourin Med 1995;71:9-12.
31 Adegbola RA, Sabally S, Corrah $\mathrm{T}$, et al. Increasing prevalence of penicillinase-producing Neisseria gonorrhoeae and the emergence of high-level, plasmid-mediated tetracycline resistance among gonococcal isolates in The Gambia. Trop Med Int Health 1997;2:428-32.

32 Chenia HY, Pillay B, Hoosen AA, et al. Antibiotic susceptibility patterns and plasmid profiles of penicillinaseproducing Neisseria gonorrhoeae strains in Durban, South Africa, 1990-1993. Sex Transm Dis 1997;24:18-22.

33 Ison CA, Roope NS, Dangor Y, et al. Antimicrobial susceptibilities and serotyping of Neisseria gonorrhoeae in southern Africa: influence of geographical source of infection. Epidemiol Infect 1993;110:297-305.

34 Chalkley LJ, van Vuuren S, Ballard RC, et al. Characterisation of penA and tetM resistance genes of Neisseria gonorrhoeae isolated in southern Africa-epidemiological monitoring and resistance development. S Afr Med F 1995;85: 775-80.

35 Knapp JS, Brathwaite AR, Hinds A, et al. Plasmid-mediated resistance in Neisseria gonorrhoeae in Kingston, Jamaica: 1990-1991. Sex Transm Dis 1995;22:155-9.

36 Dillon JR, Carballo M, King SD, et al. Auxotypes, plasmid contents, and serovars of gonococcal strains (PPNG and non-PPNG) from Jamaica. Genitourin Med 1987;63:233-8. 